\section{Grants and Awards}

Professor RUTH BowDEn, professor of anatomy at the Royal Free Hospital Medical School, and her collaborator, Mrs. DOREEN BLAKE, a medical librarian, share this year's Library Association Wheatley medal award for compiling the index of the first hundred years of the fournal of Anatomy, published last year by Cambridge University Press.

\section{Recent Publications}

Hospital Service Directory 1969, issued by the Northern Ireland Hospitals Authority, 25 Adelaide Street, Belfast, BT2 8FG.

A directory of whole-time hospital chaplains in England and Wales has been compiled. Copies of the publication can be obtained from the Hospital Chaplaincies Council, Church House, Dean's Yard, London S.W.1.

\section{Coming Events}

National Birthday Trust Fund.-Dame Juliet Rhys-Williams memorial lecture, "The Safety of Mother and Child," by Sir GeORGE Godber, 4 June, 5 p.m., Royal College of Physicians of London.

Michael Cross Memorial Lecture._-"The Plasma Kinin System: Fact and Fancy," by Sir Ashley Miles, F.R.S. ; 5 June, 5 p.m., Royal College of Surgeons of England. Admission is free, without ticket, to all those interested.

British Allergy Society.-Symposium, "Reaginic Antibody (IgE) in Allergic Disease," 6 June, 10 a.m., Royal College of Physicians, London. Fee $£ 1$ 10s. Details from Dr. K. M. Citron, Brompton Hospital, London S.W.3.

British Society for Research on Ageing and the Ciba Foundation.-Symposium, "Vascular Changes during Ageing," 2 p.m., and Ciba Foundation lecture on ageing research, "Ageing as Information Loss," by Dr. Alex Comfort, 5.30 p.m., 12 June, Royal Society of Medicine, 1 Wimpole Street, London W.1. Both are open to all interested, without fee or ticket.

Indian Medical Service.-Annual dinner, 27 June, East India and Sports Club, St. James's Square, London S.W.1. Applications to Dr. P. H. Addison, Medical Defence Union, Tavistock House South, Tavistock Square, London W.C.1.

\section{Societies and Lectures}

For attending lectures marked a fee is charged or a ticket is required. Applications
made first to the institution concerned.

\section{Monday, 26 May}

Royal Postgraduate MEdical School.-9.30 a.m., Professor A. S. Burgen: Molecular Basis of Drug Action.

SCOTTISH TELEVISION.-11.20 p.m., Postgraduate medicine: Cleft Palate. (Sponsored by Newcastle Postgraduate Medical Board.)

Tuesday, 27 May

B.B.C. 1 Television.-11.27 p.m. (approx.), Medicine Today: Contraception-Choice of Method. Croydon

12 Mon Medical Centre.-At Mayday Hospital 12.30 p.m., Dr. R. Danbury: Manipulatio FOREST Associated Treatment in General Practice. OREST MEDICAL SOCIETY.-At Whipps Cro pital, Londion E., 1 p.m., clinical meeting.
HAREFIELD AND NoRTHWOOD POSTGRADUATE MEDICAL CENTRE.-At Mount Vernon Hospital, 8.30 p.m., clinicopathological conference by Dr. P. Knight.

INSTITUTE OF DeRMatology.-4.30 p.m., Dr. J.
Greeves: Psychosomatic Aspects of Skin Disease.
INSTITUTE OF OBSTETRICS AND GYNAECOLOGY.-At Hammersmith Hospital, (1) 2 p.m., Dr. M. Kerr: Problems of Sex and Contraception ; (2) nancy.

King's College Hospital Medical School.-5.30 p.m., (1) Mr. St. J. D. Buxton: Orthopaedics at King's-The Origin and Period 1919 to 1929: (2) Sir Cecil Wakeley: The Life and Times of F. F Burghard C.B., M.S., F.R.C.S., 1864-1947. KInGSTON-UPON-THAMES MEDICAL CENTRE. -2.30
p.m., Miss H. A. Oliver: Care of the Unsupported Mother.
Neath Postgraduate Medical Centre.-At Neath General Hospital, 4.30 p.m., Dr. B. Roper: Arteriography.

ROYAL ARMY MEDICAL College.-5 p.m., Mr. R. P. G. Sandon: A Question of Skin Cover: p.m., session in new physiological concepts of
clinical disease by Dr. M. Lessof: Mechanisms of Immunology.

Royal STATISTICAL Society: MEdical SECTION.At Manson Theatre, London School of Hygiene and Tropical Medicine, 5 p.m., Dr. J. Marshall, Different Days of the Menstrual Cycle.

WESTMINSTER MEDICAL SCHOOL.-At Page Street lecture theatre, 5.15 p.m., current work by Mr. D. Morgan: The Computer.

Wednesday, 28 May Chiltern Medical Centre.-At Wycombe General
Hospital, High Wycombe, 12.15 p.m., Mr. N. Thompson: Current Aspects of Reconstructive Surgery.

Went Postgraduate Medical Centre.-At Royal Gwent Hospital, Newport, Mon., 2.15 p.m., clinicopathological conference, and obstetrics and
gynaecology meeting.
HORDER CLUB. - At Medical Centre, Royal Northern

Hospital, London Nedical Centre, Royal Northern Hospital, London N.7, 8.30 p.m., Mr. H. H. G. Eastcott: Second Thoughts on Arterial Surgery.
INSTITUTE of NEURoLOGY.-(1) 6 p.m., Mr. A. E. Richardson: The Neurosurgeon and Uses of Radiotherapy ; (2) 7 p.m., Dr. H. J. G. Bloom: Principle, Practice, and Results in Tumours of Nervous System.

INSTITUTE OF ORTHOPAEDICS.- -8.15 p.m., Mr. P. H.
Newman: Newman: Clinical Syndromes of Mechanical Derangements of the Spine-I, Instability and
Spinal Stenosis.

INSTITUTE OF PSYCHIATRY. -5.30 p.m., Dr. W.
Warren: Management of the Adolescent Patient Warren: Management of
in a Psychiatric Hospital.

OXFORD UNIVERSITY.-At Nuffield Department of Medicine lecture theatre, Radcliffe Infirmary, 5 p.m., Professor J. N. M.

ROYAL POSTGRADUATE MEDICAL SCHOOL.-(1) 9.30 a.m., Professor D. A. Price Evans: Individual Variations in Drug Metabolism ; (2) 10.15 a.m. medical staff round; (3) 11.45 a.m., clinicopatho logical conference: Renal Biopsy. Session; (4) 2 p.m. Dr. M. T. Parker: Investigation of Sepsis in Hospitals due to Gram-negative Rods.

COTTISH TELEVISION. -12.45 p.m., Postgraduate medicine: Cleft Palate (repeat). (Sponsored by Newcastle Postgraduate Medical Board.)

OUTHAMPTON POSTGRADUATE MEDICAL FEDERATION. -At Medical Centre, Southampton General Hospital, 6 p.m., film: Fibrogastroscopy.

TOKE MANDEville Hospital.-12.15 p.m., Mr. W. R. L. Pryer: clinical cases. p.m., film: The Acute Abdomen.

W.m., fulm: The Acute Abdomen. At Outpatient Department, West Suffolk General Hospital, Bury St. Edmunds, 8.15 p.m., clinical

meeting. Centre, Archway Wing, 11.30 a.m., Dr. F.
Dudley Hart: Management and Treatment of
Rheumatoid Arthritis.

Thursday, 29 May

ABERDEEN UNIVERSITY.-At Medical School Foresterhill, 5 p.m., Professor R. W. Smithells:
His or Hers? Some Problems of Sex Development. FACULTY

OF HOMOEOPATHY.-5 p.m., meeting: LEEDS MEDICAL SCIENCES CLUB.-Ait Littlewood Hall, General Infirmary at Leeds, 7 p.m., papers will be read.

LEEDS UNIVERSITY.-At Rupert Beckett lecture theatre, 3 p.m., Moynihan lecture by Mr. N. C. Tanner: The Surgeon Physiologist:

Neath Postgraduate Medical Centre.-At Neath General Hospital, 4.30 p.m., cases and discussion by paediatric department.
ST. MARY's Hospital MEDICAL SCHOOL.-A Wright-Fleming Institute Theatre, 5 p.m., Mr.
A. Klopper: Oestriol Assay as Measure of
Placental Function.

SOCIETY FOR ENDOCRINOLOGY.-At Zoological Society of London (meeting house), 5.30 p.m., Dale lecture by Professor S. J. Folley, F.R.S.: The Milk logy, Myth, and Art.

WEST, Myth, and Art. School.-At Page Stree lecture theatre, 5.15 p.m., surgical conference by Professor B. Brooke: Granulomatous Disease of

the Colon.
ROYAL POSTGRAduATE MEDICAL SCHOOL.-(1) 10
a.m., surgery staff round ; (2) 11 a.m., Mr. A. J. a.m., surgery staff round; (2) 11 a.m., Mr. A. J. Edwards: Lymph Glands in an Experimental Laurence ; (4) 2 p.m., Mr. A. K. Monro: Re- current Incisional Hernia ; (5) 3 p.m., Mr. P. M. Friday, 30 May

Neath Postgraduate Medical Centre.-At Neath General Hospital, afternoon, and evening sym-
posium: Contraception 1970's-Health and Bducational Factors.

\section{Appointments}

NORTH-WEST METROPOLITAN REgIONAL HosptTAL BOARD.-M. R. Colwill, M.B., F.R.C.S. (consultant traumatic and orthopaedic surgeon, Hillingdon Hospital, Mount Vernon Hospital) ; Pamela M. Stracey, beth Garrett Anderson Hospital); Vera A. Wilkinson, M.B., D.P.M. (consultant child psychiatrist, Slough Child Guidance Service, Slough Child Guidance Clinic, Wexham Park Hospital, Buckinghamshire County Council).

OXFORD REgIONAL HOSPITAL BOARD. - V. D. Jones M.B., M.R.C.O.G. (consultant in obstetrics and gynaecology, Swindon/Cirencester area); B. B. Oliver, M.B., D.P.M. (consultant in psychiatry, Princess Marina Hospital, Northampton); H. G.
Tough, M.B., D.P.M. (consultant in psychiatry, Northampton/Kettering area).

\section{Corrections}

\section{Treating Glandular Fever}

In the letter from Dr. F. Dudley Hart (10 May, p. 380) the dose of indomethacin should have read $25 \mathrm{mg}$. capsules three or four times a day after food.

\section{Nutrition and Age}

We regret that in the leading article "Nutrition and Age" (17 May, p. 396) the name of Professor C. E. Dent was misspelt.

Drugs for Tuberculosis

In a letter by Dr. William D. Gray (3 May, p. 316) we regret that Dr. W. Griffel's name was misspelt.

\section{Notice to Authors}

When original articles and letters for publication are not submitted exclusively to the British Medical fournal this must be stated.

Correspondence on editorial business should be addressed to the Editor, British Medical Fournal, B.M.A. House, Tavistock Square, London W.C.1. Telephone: 01-387 4499. Telegrams : Aitiology, London W.C.1.

Authors wanting reprints of their articles should notify the Publishing Manager, B.M.A House, Tavistock Square, W.C.1, on receipt of proofs.

\section{Subscriptions}

Members' subscriptions should be sent to the Secretary of the British Medical Association B.M.A. House, London, or to the Scottish Secretary, B.M.A. Scottish Office, Drumsheugh Gardens, Edinburgh.

Doctors who are not members of the B.M.A can subscribe to the B.M.F. The rates for doctors resident in the United Kingdom and abroad are given on the first page of the classified advertisements. These include the rate for the North American "Air Express," which is available to both members and non-members of the B.M.A.

\section{Classified Advertisements}

Doctors Abroad.-Copies of the appointment vacancies advertised in the B.M.f. can be sent by airmail on request. The minimum cest is 3s. per week, for which copies of vacancies in up to five sections of the classified advertisements will be sent. The cost of each further section after five is 1s. Orders for specific grades in any section cannot be accepted. Payments should be enclosed with the order.

Details of rates, etc., for classified advertisements appear on the first page of the classified section. 